\title{
IEEJ Fundamentals and Materials Society News Letter
}

電気学会基礎・材料・共通部門（A 部門）ニュースレター 2015 年 10 月号

\section{研究グループ紹介 新潟大学 超域学術院ナノ構造制御による高機能化・新機能創製と 革新的電子デバイスへの応用研究グループ}

\section{1. はじめに}

当研究グループは加藤景三教授をプロジェクトリーダー として, 新潟大学内では金子双男理事, 自然科学系教員の 坪井 望教授, 新保一成教授, 清水英彦准教授, 大平泰生准 教授, 超域学術院の馬場暁准教授, さらに本年 7 月から新 たに加わった Chutiparn Lertvachirapaiboon 特任助教 (自 然科学系）で共同研究を行っています。超域学術院は平成 15 年度に設置された分野横断型研究特化組織で, 我々のグ ループの「ナノ構造制御による高機能化・新機能創製と革 新的電子デバイスへの応用」が，創成科学研究部門のプロ ジェクトとして選定されています。これにより, 電気電子 工学・物理・化学・生命物理に関わる, 電子デバイスや高 感度ガス・バイオセンサ等への応用に向けた基盤研究を行 っています。特に，ナノサイズの加工や観測を可能にする 近接場光や表面プラズモンを用いて研究を進めています。

\section{2. 研究 - 活動内容}

当グループの研究・活動内容を以下に紹介いたします。

金属にある条件のもとで光照射すると，金属表面の自由 電子振動と光の結合モードである表面プラズモンを励起で きます。これは金属及び誘電体の膜厚や複素屈折率に敏感 に応答する共鳴現象で, これを用いて薄膜の構造評価や吸 着センシングが可能となります。我々は表面プラズモンに ついて, 複数物質の測定が可能な多チャンネルセンサや, 水晶振動子微量天秤法との複合センシングも提案していま す。この複合センサでは, 薄膜の膨潤・収縮を検知でき, 通常よりも詳細な吸着測定が可能となります。

表面プラズモンの励起にはプリズムを用いるのが一般的 ですが，グレーティング構造を用いることもでき，この場 合は透過型の測定（T-SPR）も可能です。図 1 はポリアニ リン（PANI）薄膜の電気化学ドーピング・脱ドーピングに 伴う T-SPR 特性の変化を観測したものです。この手法は高 感度であると共に光学系が簡便で, 新規な光素子や種々の センシングへ広く応用が期待できます。

また，プリズム表面で光を全反射させた際に生じるエバ ネッセント光（プリズム表面に局在した，近接場光の一種） を合成し，これを用いて薄膜加工を行っています。この手 法によれば，通常の伝搬光よりも小さいサイズで様々な加 工が可能となります。さらに，このようなナノ構造の上へ エレクトロスプレー法によりナノドロップレットを作製し, 配列制御する試みも行っています。

この他, ワイドギャップ半導体のエピタキシャル成長と

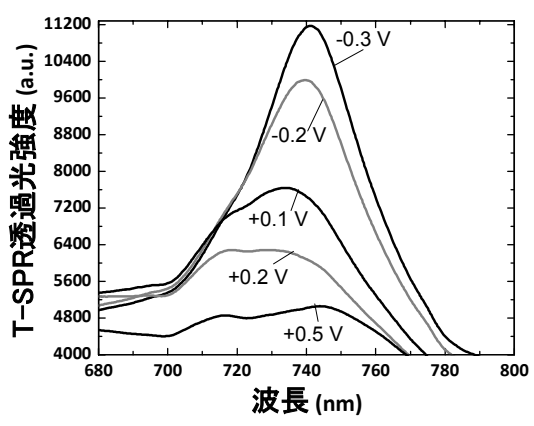

図 1 PANI 薄膜の T-SPR 特性（A. Baba, et al., Adv. Funct. Mater., 22 (2012) 4383.)

短波長発光素子の開発，マグネシウム系薄膜調光ミラー, エレクトロスピニング法によるナノ構造の作製とセンサ応 用, キャリア発生層挿入有機薄膜トランジスタなどの研究 を進めています。

なお, 加藤景三教授を委員長として, 平成 26 年 7 月より 先進ナノ構造制御と高性能有機デバイス・ライフサイエン 応用調查専門委員会調查専門委員会が活動しています。 本委員会は国内の研究機関から 23 名のメンバーが参加し て, 先進ナノ材料とナノ構造制御技術, ナノ材料・デバイ スの表面・界面物性と評価技術, ナノ材料および有機薄膜, 複合膜のナノ構造制御と電子 - 光機能, ナノ材料および有 機薄膜, 複合膜の高性能有機デバイス応用とライフサイエ ンス応用などの調査を通して, 電気電子材料分野の発展に 向けて活動をしています。

当グループでは, 米国ジョージア大学やケースウェスター ンリザーブ大学, タイのチュラロンコン大学, チェンマイ 大学, マヒドン大学, シンガポール国立材料工学研究所, 東京工芸大学, 長岡高専等の国内外の研究者と積極的に共 同研究や交流を続けています。特にタイの 3 大学からはダ ブルディグリープログラム（派遣国の大学と新潟大学双方 から同時に博士号を取得できる制度）により多くの博士後 期課程学生を受け入れており，学生の派遣も行っています。

\section{3. おわりに}

今後も国内外の研究者と積極的に交流活動を継続すると ともに, メンバーの力を結集することで研究内容をさらに 高め, 次世代を担う技術者や研究者となる学生を育成して いきたいと考えております。

新保 一成 (新潟大学自然科学系工学部担当)

(2015 年 7 月 20 日受付) 